\title{
KARAKTERISASI LAJU ALIRAN MASSA PADA PIPA BAGIAN HEATER BERDASARKAN PERUBAHAN DAYA DI UNTAI (FASSIP-01) MOD.1
}

\author{
Ahmad Fauzi ${ }^{1)}$,Mulya Juarsa ${ }^{2)}$, Rudi Irawan ${ }^{1)}$, Giarno $^{2)}$, G.B. Heru K ${ }^{2)}$, Dedy Haryanto ${ }^{2)}$, Joko ${ }^{2)}$ \\ ${ }^{1}$ Program Studi Teknik Mesin, Fakultas Teknik dan Sains, Universitas Ibn Khaldun Bogor \\ ${ }^{2}$ Pusat Teknologi dan Kesalamatan Nuklir - BATAN \\ e-mail: ahmadfauzi2829@gmail.com
}

\begin{abstract}
ABSTRAK
Kecelakaan reaktor nuklir di Fukushima Daiichi Jepang pada 11 Maret 2011, menyebabkan dilakukannya penelitian ini di berbagai negara termasuk Indonesia yang sedang mengembangkan sistem keselamatan pasif dengan alat Untai FASSIP-01 Mod.1 di PTKRN-BATAN Serpong. Ada beberapa komponen pada Untai FASSIP-01 Mod.1 yaitu komponen pemanas yang dinamakan Blanket Ceramic Heater (BCH-02), komponen pendingin dengan sistem refrigerant cooling system (RCS), dan tabung ekspansi. Sistem pasif menerapkan hukum alami untuk mengamati kondisi yang tidak stabil pada reaktor. Perlu dilakukannya eksperimen untuk mengetahui karakterisasi distribusi temperatur pada pemanas BCH-02 di Untai FASSIP-01 Mod.1 dengan memvariasikan daya dan tegangan 20 volt - 160 volt. Pengujian dilakukan selama 120 menit dan tegangan dinaikkan sebesar 20 volt selama 15 menit, eksperimen pada $\mathrm{BCH}-02$ dilakukan dengan posisi vertikal dan horizontal. Hasil eksperimen pada $\mathrm{BCH}-02$. Pada posisi vertikal perubahan temperatur terhadap waktu paling tinggi adalah T-CER mencapai $240.63^{\circ} \mathrm{C}$ dan pada posisi horizontal perubahan temperatur terhadap waktu paling tinggi adalah $\mathrm{TH}-04$ mencapai $360,83^{\circ} \mathrm{C}$. semakin besar daya yang diberikan maka temperaturnya semakin tinggi. Temperatur yang berada di permukaan ceramic-brick lebih tinggi dibandingkan dengan temperatur di dalam pipa section, hal ini disebabkan karena terjadi heat loss pada celah celah ruang di dalam BCH-02 sebelum mencapai pipa section.
\end{abstract}

Kata kunci : BCH-02, Distribusi temperatur, Kesalamatan PLN, Untai FASSIP-01 MOD.1.

\section{ABSTRACT}

Accident of a nuclear reactor at Japan's Fukushima Daiichi on March 11, 2011, led to this research in various countries including Indonesia which is developing a passive safety system with the FASSIP-01 Mod.1 tool in the PTKRN-BATAN Serpong. There are several components in the FASSIP01 Mod.1 Strand, namely the heating component called Blanket Ceramic Heater (BCH-O2), cooling components with the refrigerant cooling system (RCS), and expansion tubes. The passive system applies natural laws to observe unstable conditions in the reactor. Experiments are needed to determine the characterization of temperature distribution at BCH-02 heaters in Strand FASSIP-01 Mod.1 by varying the power and voltage of 20 volts-160 volts. The test was carried out for 120 minutes and the voltage was increased by 20 volts for 15 minutes, experiments on BCH-02 were carried out in vertical and horizontal positions. The experimental results on $\mathrm{BCH}-\mathrm{O} 2$. In the vertical position the temperature change with respect to the highest time is T-CER reaching $240.63{ }^{\circ} \mathrm{C}$ and in the horizontal position the temperature change with the highest time is $\mathrm{TH}-04$ reaching $360.83{ }^{\circ} \mathrm{C}$. the greater the power is given, the higher the temperature. The temperature on the ceramic-brick surface is higher than the temperature in the section pipe, this is due to heat loss in the space gaps in the $\mathrm{BCH}-02$ before reaching the section pipe.

Keywords : BCH-02, FASSIP-01 MOD.1, Temperature distribusion, Safety of PLN.

\section{PENDAHULUAN}

Masalah energi merupakan isu penting yang sedang hangat dibicarakan. Pemanasan global yang diyakini sedang terjadi dan memasuki tahap yang mengkhawatirkan. Maka dari itu, perlu mencari sumber-sumber energi alternatif yang cukup potensial untuk menggantikannya, salah satunya dengan mengembangkan energi tenaga nuklir di Indonesia.

Pembangkit Listrik Tenaga Nuklir (PLTN) adalah sebuah pembangkit daya termal yang menggunakan satu atau beberapa reaktor nuklir sebagai sumber panasnya yang perlu 
dipertimbangkan karena energi ini dapat menghasilkan daya hingga mencapai $2000 \mathrm{MWe}$ (BATAN, 2018). Penggunaan energi nuklir melalui PLTN sampai saat ini memberikan sekitar $15 \%$ dari kebutuhan listrik dunia, akan tetapi dalam penggunaannya, energi nuklir perlu memperhatikan beberapa aspek yang ada, antara lain aspek keselamatan, sosial, ekonomi, teknis, sumberdaya manusia, dan teknologi (Syam dan Septilarso, 2011).

Beberapa kecelakaan yang pernah terjadi pada PLTN diantaranya kecelakaan Three Mile Island Unit 2 (TMI-2) pada tahun 1979 dan Fukushima Daiichi Jepang pada tahun 2011. Reaktor TMI-2 merupakan jenis reaktor air yang bertekanan PWR (Pressurized Water Reactor) dan termasuk kategori kecelakaan parah. Pemicu kecelakaan ini adalah, hilangnya sebagian besar air pendingin LOCA (Loss of Coolant Accident) di sistem primer, dimana kejadian ini dapat dipersamakan dengan peristiwa kecelakaan air pendingin untuk kebocoran skala kecil. Dalam peristiwa kecelakaan tersebut sehingga teras dari dalam bejana tekan reaktor RPV (Reactor Presure Vessel) meleleh dan sekitar 20 ton lelehan panas bertemperatur sekitar $1130^{\circ} \mathrm{C}$ terkumpul pada bagian daerah plenum (Lower Plenum) RPV (Juarsa dan Antariksawan, 2007).

Akibat dari beberapa kecelakaan yang pernah dialami oleh beberapa reactor nuklir, perancangan dan produsen PLTN terus berupaya untuk lebih mengembangan dan meningkatkan aspek keselamatan. Salah satu konsep yang terus dikembangkan adalah system keamanan pasif. Sistem keselamatan pasif memiliki prinsip dasar proses konveksi alamiah dan sirkulasi alam (Juarsa, 2016).

Laju aliran sirkulasi alam pada siklus tertutup ini dipengaruhi oleh beberapa parameter, yaitu ukuran diameter pipa, panjang pipa dan beda ketinggian daerah dingin dan panas. Selain itu temperatur juga mempengaruhi laju aliran. Untuk kebutuhan penelitian terkait sistem pendingin pasif, Badan Tenaga Nuklir Nasional (BATAN) Pusat Teknologi Keselamatan Reaktor Nuklir (PTKRN) sedang mengembangkan Untai Fasilitas Simulasi Sistem Pasif Unit 1 (FASSIP-01). Komponen Untai FASSIP-01 terdiri dari BCH-02 (blanket ceramic heater), RCS (Refrigrant Cooling System) dan tabung ekspansi yang terhubung pada pipa dalam posisi vertikal membentuk untai rektangular. Kasus sirkulasi alam diperkirakan memiliki kondisi aliran yang berbeda di daerah panas (BCH-02) yang posisi di bawah, dengan daerah dingin (RCS) yang posisinya di atas. Sehingga, analisis berdasarkan data eksperimen terhadap karakterisasi distribusi temperatur pada komponen pemanas BCH- 02 di Untai FASSIP-01 Mod.1(Fauzi, 2018).

Beberapa penelitian keselamatan sistem pasif telah dilakukan oleh Chung et al. (2016) tentang kode TASS / SMR yang dikembangkan menggunakan berbagai model termohidrolik yang mencerminkan fitur desain SMART, seperti penukar panas kondensat dalam sistem pembuangan panas residual pasif. Sistem Pendingin Moderator Pasif (PMCS) dari Advanced Heavy Water Reactor dirancang untuk menghilangkan panas dari moderator secara pasif dalam kasus kondisi keluar stasiun hitam yang diperpanjang atau Station Black Out (SBO) (Pal et al., 2016). Wu et al. (2017) mempertimbangkan efek resistensi lokal dan ketahanan gesekan dalam loop sirkulasi alami, hubungan analitis antara laju aliran massa sirkulasi alami dan daya pemanasan $(Q)$ dapat dinyatakan sebagai $G Q m ; m$ 1/4 Re; Rn, dimana $R n$ adalah rasio dari koefisien kehilangan tekanan lokal dan koefisien gesekan. Naveen et al. (2014) mensimulasikan start-up loop yang memiliki orientasi heater dan cooler yang berbeda dan penerapan model sebagai alat umum untuk mensimulasikan start-up loop sirkulasi alami persegi panjang dinilai. VHTR prismatik, blok grafik berbentuk heksagonal dibor untuk memungkinkan penyisipan pin bahan bakar, terbuat dari partikel bahan bakar tristructural-isotropic yang dipadatkan, dan saluran pendingin untuk pendingin helium (Tung et al., 2014). Menurut Wang et al. (2014), hubungan antara laju aliran rata-rata siklus sebelum dan sesudah gerakan mulai bergulir, dan hubungan antara parameter gerakan bergulir, amplitudo denyut terelatif dari bilangan Nusselt dan bilangan Reynolds rata-rata siklus, bilangan Nusselt sesaat dalam kondisi gerak bergulir dapat diprediksi menggunakan parameter termal-hidrolik dalam kondisi statis. Keakuratan dan penerapan metode penskalaan yang diusulkan ini ditunjukkan dengan mengusulkan loop sederhana dan sistem seperti Pressurized Water Reactors (PWR), dengan sistem untuk mendapatkan dua model yang sesuai (Yu dan Choi, 2016).

\section{METODE PENELITIAN}

Penelitian ini dilakukan pada alat Untai FASSIP-01 Mod.1 yang mempelajari karakteristik pendinginan sirkulasi alam dengan menggunakan air sebagai fluida kerjanya. Skema Untai FASSIP01 Mod.1 dapat dilihat pada Gambar 1 dan 2. 
Gambar 1 dan 2, alat Untai FASSIP-01 Mod.1 memiliki beberapa komponen utama yang meliputi tabung ekspansi, RCS dan BCH-02. Penelitian ini bertujuan untuk mengetahui hasil perhitungan laju aliran massa dan karakterisasi perubahan temperatur pada komponen pemanas $\mathrm{BCH}-02$ berdasarkan perubahan daya heater pada Untai FASSIP -01 Mod.1.

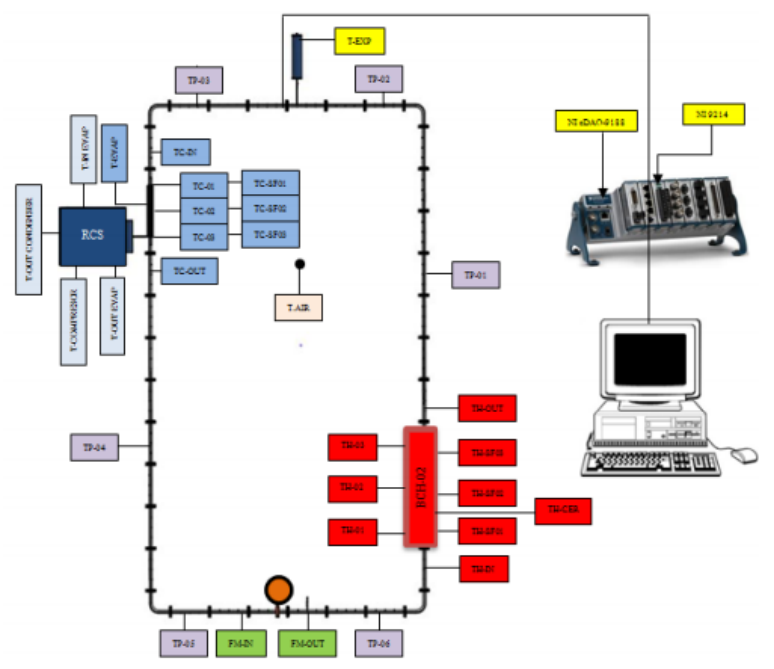

Gambar 1. Skema Untai FASSIP-01 Mod.1

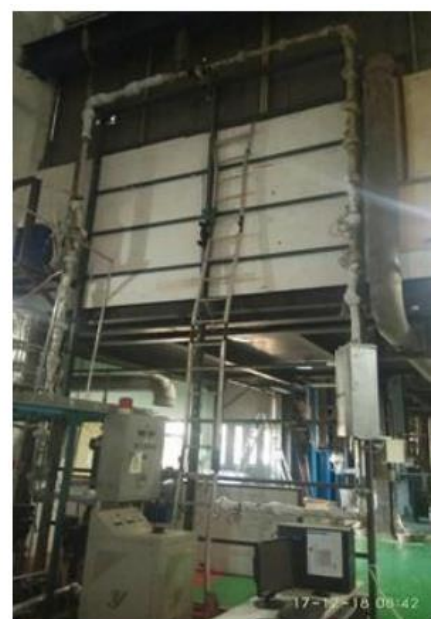

Gambar 2. Untai FASSIP-01 Mod.1

BCH-02 merupakan sebuah alat pemanas kontak langsung yang dipasangkan kawat heater sebanyak 8 kawat yang dililit masing-masing kawat sebanyak 11 lilitan. BCH-02 mempunyai panjang $92 \mathrm{~cm}$ dan lebar $13 \mathrm{~cm}$ x $13 \mathrm{~cm}$. Bagian konduktor penghubung dari kawat pemanas ke pipa section dengan ceramic-brick. Gambar BCH02 dapat dilihat pada Gambar 3.

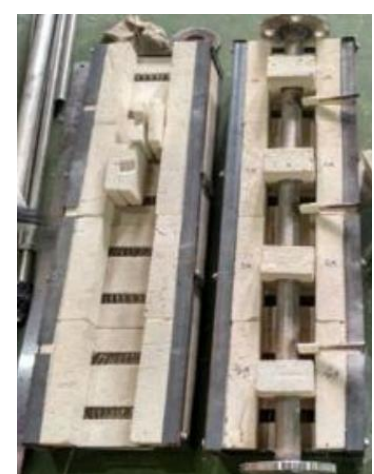

Gambar 3 BCH-02

Dapat kita lihat pada Gambar 3 untuk mendapatkan hasil data perhitungan laju aliran massa dan karakterisasi distribusi temperatur pada komponen BCH-02, maka perlu dilakukan pemasangan termokopel pada bagian-bagian yang sudah ditentukan guna mengetahui perubahan temperatur pada BCH-02. Ada 7 termokopel yang dipasang pada $\mathrm{BCH}-02$ dengan posisi vertikal dan 6 termokopel pada posisi horizontal, berikut gambar pemasangan termokopel pada $\mathrm{BCH}-02$ dapat dilihat pada Gambar 4 dan 5 .

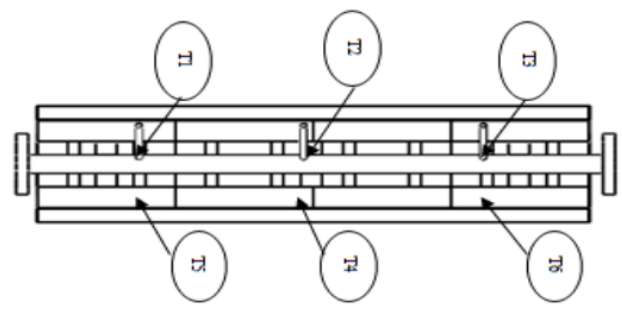

Gambar 4. Penempatan termokopel posisi horizantal

Pada Gambar 4 penempatan termokopel pada BCH-02 secara horizontal yaitu:

- Posisi T1 menempel di dalam pipa section

- Posisi T2 menempel di dalam pipa section

- Posisi T3 menempel di dalam pipa section

- Posisi T4 menempel di atas ceramic-brick

- Posisi T5 menempel di atas ceramic-brick

- Posisi T6 menempel di atas ceramic-brick

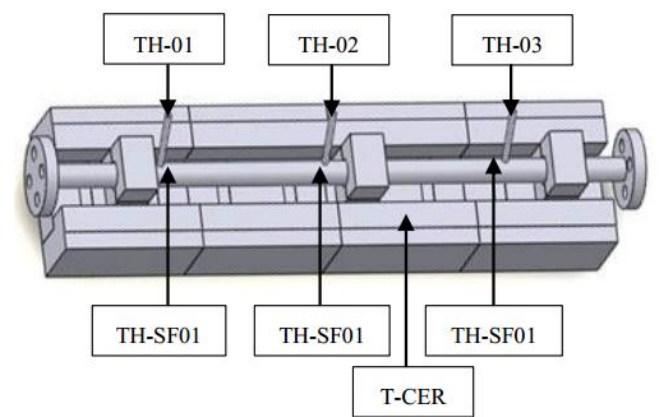

Gambar 5. Penempatan termokopel posisi vertikal 
Pada Gambar 5 penempatan termokopel pada BCH-02 secara vertikal yaitu:

- Posisi TH-01 berada di dalam pipa section

- Posisi TH-02 berada di dalam pipa section

- Posisi TH-03 berada di dalam pipa section

- Posisi TH-SF01 di atas permukaan pipa

- Posisi TH-SF02 di atas permukaan pipa

- Posisi TH-SF03 di atas permukaan pipa

- Posisi TH-CER menempel di permukaan ceramic-brick.

Termokopel yang sudah dipasang pada BCH-02 dihubungkan ke Modul National Instrument (NI) yang berfungsi untuk menghubungkan pembacaan temperatur dari termokopel oleh aplikasi pada komputer. Aplikasi yang digunakan adalah LabView untuk mengamati suhu pada BCH-02 di komputer. Adapun penelitian ini dilakukan berdasarkan diagram alir seperti pada Gambar 6.
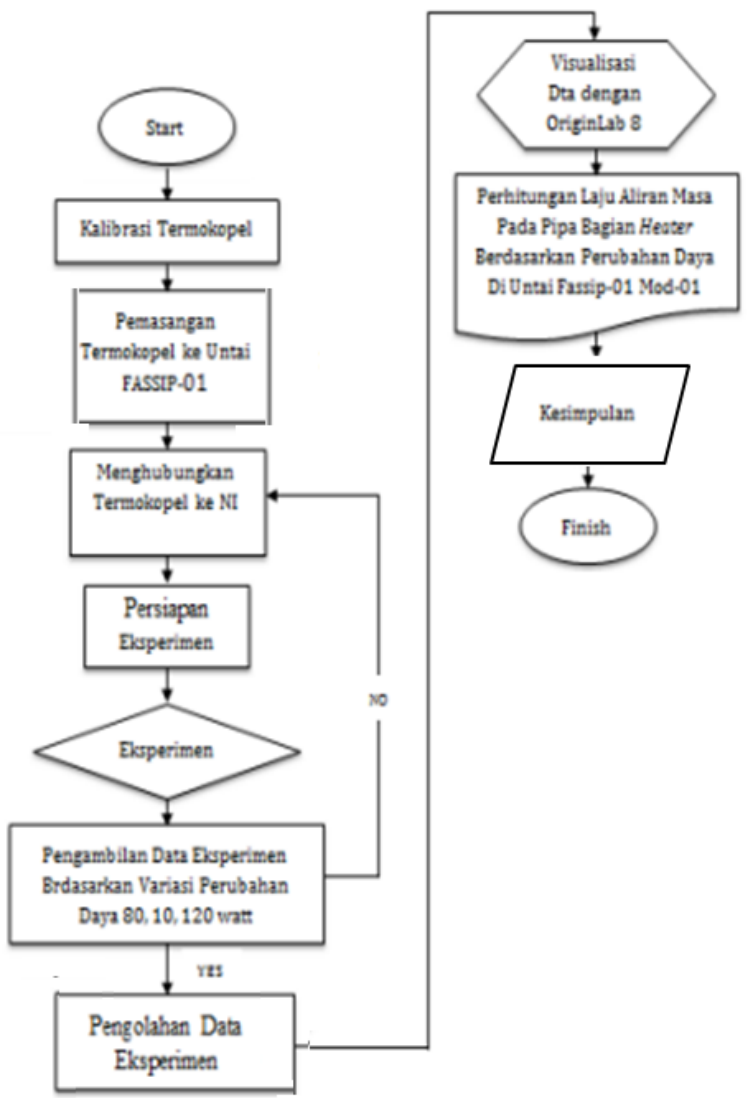

4tjjop

Gambar 6. Diagram alir Penelitian

Eksperimen ini dilakukan selama 105 menit, pada setiap 15 menit tegangan dinaikkan sebesar 20 volt pada regulator voltage.

\section{HASIL DAN PEMBAHASAN}

Setelah melakukan eksperimen dan pengambilan data temperatur pada $\mathrm{BCH}-02$ maka didapatkan data pada Tabel 1 dengan posisi vertikal dan Tabel 2 dengan posisi horizontal

Tabel 1. Data pengujian pada $\mathrm{BCH}-02$ posisi vertikal

\begin{tabular}{cccccccc}
\hline No & Menit & $\begin{array}{c}\mathrm{V} \\
\text { (Volt) }\end{array}$ & $\begin{array}{c}\mathrm{I} \\
\text { (A) }\end{array}$ & $\begin{array}{c}\mathrm{P} \\
\text { (Watt) }\end{array}$ & $\begin{array}{c}\text { TH-01 } \\
{ }^{\circ} \mathrm{C}\end{array}$ & $\begin{array}{c}\text { TH-02 } \\
{ }^{\circ} \mathrm{C}\end{array}$ & $\begin{array}{c}\text { TH-03 } \\
{ }^{\circ} \mathrm{C}\end{array}$ \\
\hline 1 & 15 & 0 & 0,00 & 0 & 26,16 & 26,12 & 26,30 \\
\hline 2 & 30 & 20 & 2,50 & 50,0 & 26,22 & 26,80 & 27,10 \\
\hline 3 & 45 & 40 & 4,36 & 174,4 & 27,40 & 28,97 & 30,01 \\
\hline 4 & 60 & 60 & 6,54 & 392,4 & 30,27 & 34,07 & 37,17 \\
\hline 5 & 75 & 80 & 8,84 & 707,2 & 35,11 & 42,13 & 47,21 \\
\hline 6 & 90 & 100 & 11,90 & 1190,0 & 44,06 & 52,91 & 61,16 \\
\hline 7 & 105 & 120 & 14,60 & 1752,0 & 56,59 & 70,71 & 77,88 \\
\hline No & $\begin{array}{c}\text { V } \\
\text { (Volt) }\end{array}$ & $\begin{array}{c}\text { I A) } \\
1\end{array}$ & $\begin{array}{c}\text { P } \\
\text { (Watt) }\end{array}$ & $\begin{array}{c}\text { TH-SF01 } \\
{ }^{\circ} \mathrm{C}\end{array}$ & $\begin{array}{c}\text { TH-SF02 } \\
{ }^{\circ} \mathrm{C}\end{array}$ & $\begin{array}{c}\text { TH-SF03 } \\
{ }^{\circ} \mathrm{C}\end{array}$ & T-CER \\
\hline 2 & 20 & 2,50 & 0 & 26,16 & 26,12 & 26,30 & 32,33 \\
\hline 3 & 40 & 4,36 & 174,4 & 27,40 & 28,97 & 30,01 & 54,07 \\
\hline 4 & 60 & 6,54 & 392,4 & 30,27 & 34,07 & 37,17 & 92,71 \\
\hline 5 & 80 & 8,84 & 707,2 & 35,11 & 42,13 & 47,21 & 116,32 \\
\hline 6 & 100 & 11,90 & 1190,0 & 44,06 & 52,91 & 61,16 & 163,94 \\
\hline 7 & 120 & 14,60 & 1752,0 & 56,59 & 70,71 & 77,88 & 240,63 \\
\hline
\end{tabular}

Dapat dilihat pada Tabel 1, pada termokopel di menit 15-105 dengan tegangan yang diberikan sebesar 20-120 volt dan arus yang mengalir 0,0014,60 amper, temperatur yang dibaca oleh termokopel terus mengalami kenaikan. Perubahan temperatur terhadap waktu diberikan oleh heater dapat dilihat pada Gambar 7.

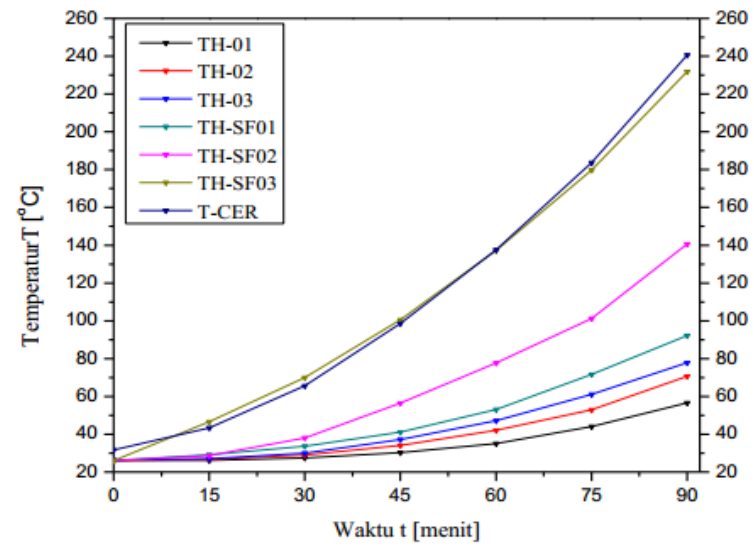

Gambar 7. Grafik temperatur terhadap waktu pada $\mathrm{BCH}-02$

Dari grafik pada Gambar 7 dapat dilihat bahwa perubahan temperatur terhadap waktu paling tinggi adalah T-CER mencapai $240.63^{\circ} \mathrm{C}$, hal ini disebabkan karena pemasangan T-CER berada di dekat kawat heater. Sedangkan temperatur paling tinggi pada pipa section berada pada TH-SF03 yang penempatannya di atas permukaan pipa section mencapai $231.85^{\circ} \mathrm{C}$ dan perubahan temperatur paling rendah adalah TH-01 mencapai $56.59^{\circ} \mathrm{C}$. Hal ini 
dikarenakan pemasangannya di dalam section pipe, sehingga panas yang diterima lebih lambat. Pada data dan grafik yang diamati, termokopel yang letaknya di permukaan pipa section memiliki temperatur lebih tinggi dari pada di dalam pipa section, itu karena termokopel yang penempatannya di atas permukaan pipa section terkontak langsung dengan alat penghantar panasnya dan di dalam pipa section terjadi perbedaan temperatur yang temperaturnya lebih rendah dari pada di permukaan pipa.

Perubahan temperatur yang didapatkan dipengaruhi oleh daya yang diberikan setiap waktu selalu mengalami peningkatan. Perubahan daya terhadap waktu dapat dilihat pada Gambar 8.

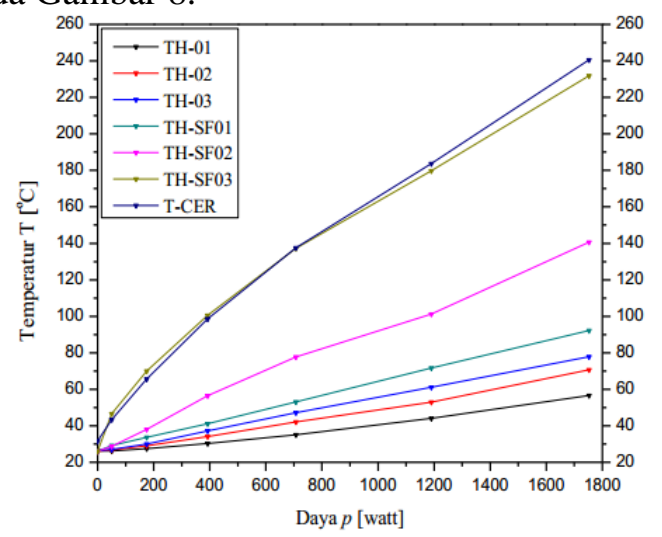

Gambar 8. Grafik temperatur terhadap daya pada $\mathrm{BCH}-02$

Dari grafik pada Gambar 8 dapat dilihat bahwa perubahan temperatur terhadap daya paling tinggi adalah 1.752 watt. Maka dari itu, semakin besar daya yang diberikan mengakibatkan perubahan temperaturnya semakin tinggi. Adapun hasil data eksperimen yang ke 2 dengan pengambilan data temperatur pada $\mathrm{BCH}-02$ dengan posisi horizontal dapat dilihat pada Tabel 2.

Tabel 2. Data pengujian $\mathrm{BCH}-02$ horizontal

\begin{tabular}{|c|c|c|c|c|c|c|c|}
\hline No & Menit & $\begin{array}{c}\mathrm{V} \\
\text { (Volt) }\end{array}$ & $\begin{array}{c}1 \\
\text { (A) }\end{array}$ & $\begin{array}{c}\text { P } \\
\text { (Watt) }\end{array}$ & $\begin{array}{c}\text { TH-01 } \\
{ }^{\circ} \mathrm{C}\end{array}$ & $\begin{array}{c}\text { TH-02 } \\
{ }^{\circ} \mathrm{C}\end{array}$ & $\begin{array}{c}\text { TH-03 } \\
{ }^{\circ} \mathrm{C}\end{array}$ \\
\hline 1 & 15 & 0 & 0,00 & 0 & 32,01 & 33,13 & 34,66 \\
\hline 2 & 30 & 20 & 2,50 & 50,0 & 34,01 & 35,44 & 36,93 \\
\hline 3 & 45 & 40 & 4,36 & 174,4 & 42,42 & 43,63 & 43,18 \\
\hline 4 & 60 & 60 & 6,54 & 392,4 & 68,06 & 68,05 & 66,5 \\
\hline 5 & 75 & 80 & 8,84 & 707,2 & 10769 & 108,69 & 102,59 \\
\hline 6 & 90 & 100 & 11,90 & 1190,0 & 166,59 & 169,96 & 159,27 \\
\hline 7 & 105 & 120 & 14,60 & 1752,0 & 251,09 & 257,26 & 242,3 \\
\hline No & Menit & $\begin{array}{c}\mathrm{V} \\
\text { (Volt) } \\
\end{array}$ & $\begin{array}{c}\text { I } \\
\text { (A) }\end{array}$ & $\begin{array}{c}\mathbf{P} \\
\text { (Watt) } \\
\end{array}$ & $\begin{array}{c}\mathrm{TH}-04 \\
{ }^{\circ} \mathrm{C}\end{array}$ & $\begin{array}{c}\text { TH-05 } \\
{ }^{\circ} \mathrm{C}\end{array}$ & $\begin{array}{c}\text { TH-06 } \\
{ }^{\circ} \mathrm{C}\end{array}$ \\
\hline 1 & 15 & 0 & 0,00 & 0 & 31,38 & 31,77 & 31,77 \\
\hline 2 & 30 & 20 & 2,50 & 50,0 & 35,85 & 35,85 & 36,38 \\
\hline 3 & 45 & 40 & 4,36 & 174,4 & 49,72 & 49,72 & 47,75 \\
\hline 4 & 60 & 60 & 6,54 & 392,4 & 81,78 & 81,78 & 76,67 \\
\hline 5 & 75 & 80 & 8,84 & 707,2 & 129,38 & 129,39 & 119,29 \\
\hline 6 & 90 & 100 & 11,90 & 1190,0 & 193,77 & 193,77 & 182,57 \\
\hline 7 & 105 & 120 & 14,60 & 1752,0 & 281,35 & 281,35 & 269,37 \\
\hline
\end{tabular}

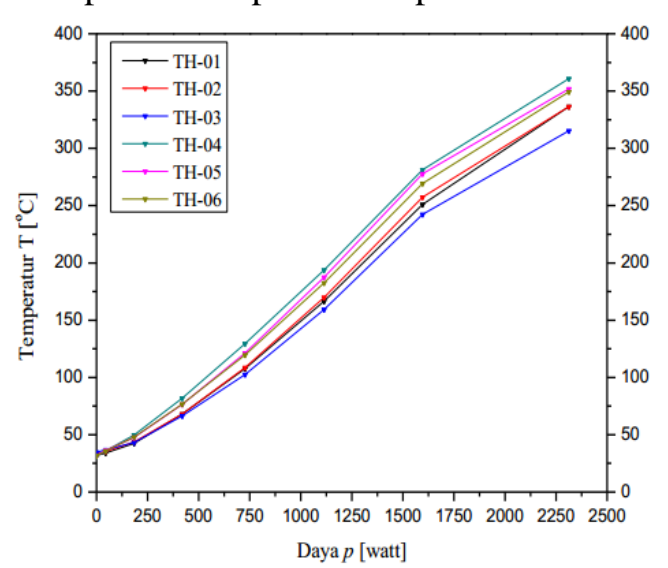

Gambar 10. Grafik temperature terhadap daya pada $\mathrm{BCH}-02$

Dapat dilihat pada Tabel 1 pada termokopel

TH-01, TH-02, TH-03, TH-04, TH-05 dan TH-06 di menit 15-105 menit dengan tegangan yang diberikan sebesar 20-120 volt dengan arus yang diberikan dari 0,00-14,60 amper, temperatur yang dibaca oleh termokopel terus mengalami kenaikan temperatur. Perubahan temperatur terhadap waktu diberikan oleh heater dapat dilihat pada Gambar 9.

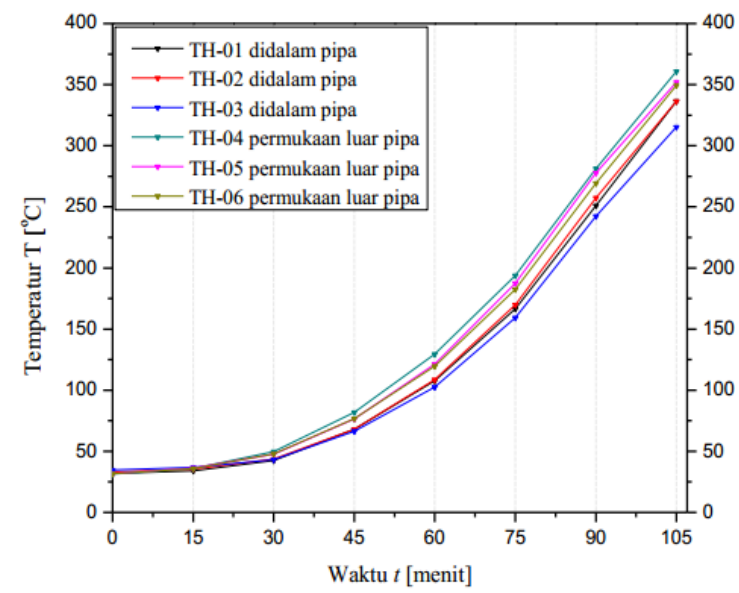

Gambar 9. Grafik temperature terhadap waktu pada $\mathrm{BCH}-02$

Dari grafik pada Gambar 9 dapat dilihat bahwa perubahan temperatur terhadap waktu paling tinggi adalah TH-04 mencapai $360,83^{\circ} \mathrm{C}$, hal ini disebabkan pemasangan $\mathrm{TH}-$ 04 berada di atas permukaann ceramic-brick. Sedangkan perubahan temperatur paling rendah adalah $\mathrm{TH}-03$ mencapai $315,42^{\circ} \mathrm{C}$, karena pemasangan termokopel di dalam pipa section, sehingga panas yang diterima lebih lambat.

Adapaun perubahan temperatur yang didapatkan dipengaruhi oleh daya yang diberikan setiap waktu terus mengalami peningkatan temperatur. Perubahan daya terhadap waktu dapat dilihat pada Gambar 10. 
Dari grafik pada Gambar 10 dapat di lihat bahwa perubahan temperatur terhadap daya paling tinggi adalah TH-04 mencapai $360,83^{\circ} \mathrm{C}$, hal ini karena pemasangan $\mathrm{TH}-04$ berada di atas di permukaan ceramic-brick. Sedangkan perubahan temperatur paling rendah adalah TH-03 mencapai $315,42^{\circ} \mathrm{C}$, karena penempatannya di dalam pipa section dengan daya yang diberikan sebesar 2.312,8 watt.

\section{KESIMPULAN DAN SARAN}

Berdasarkan hasil eksperimen yang dilakukan selama 105 menit, didapatkan perbedaan temperatur dengan posisi yang berbeda yaitu vertikal dan horizontal, hal ini bertujuan untuk mengetahui karakterisasi temperatur pada $\mathrm{BCH}-02$ dan perhitungan laju aliran massa pada pipa bagian heater berdasarkan perubahan daya di Untai FASSIP-01 Mod.1. hasil eksperimen menunjukan pada posisi vertikal perubahan temperatur terhadap waktu paling tinggi adalah T-CER mencapai $240.63^{\circ} \mathrm{C}$ dan pada posisi horizontal perubahan temperatur terhadap waktu paling tinggi adalah TH-04 mencapai $360,83^{\circ} \mathrm{C}$

\section{UCAPAN TERIMA KASIH}

Penulis mengucapkan terima kasih kepada Kepala PTKRN-BATAN atas ijinnya untuk melakukan Tugas Akhir dan penggunaan fasilitas di laboratorium Termohidrolik Eksperimental. Ucapan terima kasih juga diberikan kepada anggaran DIPA PTKRNBATAN tahun 2017 dan Hibah Luar Negeri, CRP IAEA 2017-2020 dengan nomor kontrak 20948.

\section{REFERENSI}

BATAN. (2018). Pengenalan Pembangkit Listrik Tenaga Nuklir. Retrieved from www.batan.go.id/index.php/id/infonukli r/pltn-infonuklir/generasi-pltn/924pengenalan-pembangkit-listrik-tenaganuklir website: http://www.batan.go.id

Chung, Y. J., Kim, S. H., Bae, K. H. (2016). Natural circulation heat transfer model development over vertical tube bundle in the condensate heat exchanger. Annals of Nuclear Energy, 94, 759-766. doi: https://doi.org/10.1016/j.anucene.2016.0 4.037
Fauzi, A. (2018). Karakteristik distribusi temperatur pemanas $\mathrm{BCH}-02$ di Untai FASSIP-01 Laporan kerja praktek.

Juarsa, M. (2016). Passive System Simulation Facility (FASSIP) Loop for Natural Circulation Study. Paper presented at the Proceeding of "Seminar Nasional Teknologi Energi Nuklir (SENTEN". 2016. Batam, 4-5 Agustus 2016.

Juarsa, M., Antariksawan, A. R. (2007). Boiling heat transfer phenomenon research on Three Mile Island Unit 2 nuclear reactor accident event. Sigma Epsilon, 11(2), 111.

Naveen, K., Iyer, K. N., Doshi, J. B., Vijayan, P. K. (2014). Investigations on singlephase natural circulation loop dynamics part 1: Model for simulating start-up from rest. Progress in Nuclear Energy, 76, 148-159. doi: https://doi.org/10.1016/j.pnucene.2014.0 5.017

Pal, E., Kumar, M., Nayak, A. K., Joshi, J. B. (2016). Experimental and CFD simulations of fluid flow and temperature distribution in a natural circulation driven Passive Moderator Cooling System of an advanced nuclear reactor. Chemical Engineering Science, 155(C), 45-64. doi: 10.1016/j.ces.2016.07.037

Syam, N. S., Septilarso, A. (2011). Aplikasi sistem keselamatan pasif pada reaktor nuklir. Prosiding Pertemuan Ilmiah XXV HFI.

Tung, Y.-H., Johnson, R. W., Ferng, Y.-M., Chieng, C.-C. (2014). Modeling strategies to compute natural circulation using CFD in a VHTR after a LOFA. Nuclear Engineering and Design, 275, 80-90.

doi: https://doi.org/10.1016/j.nucengdes.201 4.04 .012

Wang, C., Li, X., Wang, H., Gao, P. (2014). Experimental study on single-phase heat transfer of natural circulation in circular pipe under rolling motion condition. Nuclear Engineering and Design, 273, 497-504. doi: https://doi.org/10.1016/j.nucengdes.201 4.03.045

Wu, L., Liu, Y., Jia, H.-j., Wang, J. (2017). Innovative flow-resistance performance in the single-phase natural circulation 
loop and relevant experiment verification. International Journal of Heat and Mass Transfer, 107, 66-73. doi:

https://doi.org/10.1016/j.ijheatmasstrans fer.2016.11.043

Yu, X.-G., Choi, K.-Y. (2016). Systematic and exact scaling analysis of the singlephase natural circulation flow: The hydraulic similarity. Progress in Nuclear Energy, 89, 78-87. doi: https://doi.org/10.1016/j.pnucene.2016.0 2.001 